Vol. 3 No. 1

Juni 2021

e- ISSN $2685-0559$

p- ISSN $2684-673 X$

\title{
REPRESENTASI KUASA RAMALAN: PANGERAN DIPENOGORO DAN AKHIR TATANAN LAMA DI JAWA 1785- 1855 KARYA PETER CAREY DALAM AKU DIPENOGORO! OLEH LANDUNG SIMATUPANG
}

\author{
Nur Alifah Septiani \\ Universitas Ahmad Dahlan (UAD), Yogyakarta, Indonesia \\ nur.alifah@idlitera.uad.ac.id
}

\begin{abstract}
Literary works are never separated from previous works or other texts. "Aku Dipenogoro!" is a literary work in the form of a drama script written by Landung Simatupang which was inspired by the power of divination by Peter Carey. The process of forming a literary work based on the acceptance of the past works can be said to be a reception. Therefore, this study used a reception approach to see how far the acceptance of previous works in Aku Dipenogoro!. The method used in this study is descriptive qualitative. In this case, the researcher compares the texts by looking at the similarities and differences. Furthermore, the findings are described. Based on the results of the analysis conducted by Aku Dipenogoro! as a literary work made several changes from the previous work (Peter Carey's Power of Prediction). These changes are used to give a dramatic effect in the work. Improvisation is used to get certain effects and aesthetics in a work. As a drama script Aku Dipenogoro! refers to dramatic effects in the performing arts (theater).
\end{abstract}

Keywords: Representation, shift text, historical text, literary text

\section{PENDAHULUAN}

Kelahiran karya sastra tidak dapat dilepaskan dari karya-karya sebelumnya. Kehadiran Aku Dipenogoro! tidak terlepas dari teksteks sebelumnya yang telah menginspirasi Landung Simatupang untuk menghadirkan karya tersebut ke publik. Penerimaan sastra masa lalu yang kemudian direpresentasikan kembali dengan bentuk yang berbeda menunjukkan masih baiknya tanggapan pembaca terhadap karya tersebut. Interpretasi karya dapat bersumber dari pengetahuan dari teks dan pengetahuan yang terdapat pada peneliti (Junus, 1985). Kemampuan melakukan interpretasi atas sebuah 
Vol. 3 No. 1

Juni 2021

e- ISSN 2685 - 0559

p- ISSN 2684 - 673X

karya melibatkan pengetahuan yang luar biasa selain teks-teks lain yang mendukung. Hal tersebut seperti yang dikatakan oleh Peter Carey sebagai penulis pengantar bagi Aku Dipenogoro! karya Landung Simatupang sebagai berikut,

Tanpa melihat lebih dekat kepada detail, kehebatan Landung dalam menghidupkan kembali kisah luar biasa Dipenogoro bakal kurang dipercaya. Sebenarnya, metode kerjanya-khususnya kerja kersanya menggunakan sumber-sumber sejarahmemiliki logika tersendiri (Simatupang, 2015).

Landung Simatupang adalah seorang aktor dan sutradara teater yang lahir di Yogyakarta 25 November 1951 dan bertempat tinggal di Yogyakarta. Landung Simatupang adalah alumni Sastra Inggris Universitas Gadjah Mada, dari sanalah perkenalannya dengan dunia teater. Kemudian ia mulai terlibat dalam pementasan teater luar negeri bersama Black Swan Theater Company dari Perth, Australia. Selain itu, juga telah menyutradarai dan memainkan naskah-naskah Indonesia maupun Asing. Landung Simatupang juga pernah turut andil dalam dunia perfilaman, seperti Sang Pemimpi (2009), Garuda di Dadaku (2009), Rumah dan Musim Hujan (2010), Soegija (2011), Sang Penari (2011), Rindu Purnama (2011), Ambilkan
Bulan (2012), Rayya, Cahaya di Atas Cahaya (2012), Jokowi (2013), Optissimus (2013), Negeri Tanpa Telinga (2014), Pendekar Tongkat Emas (2014), dan Surga yang Tak Dirindukan (2015). Landung Simatupang juga pernah mendapatkan penghargaan dalam Festival Film Indonesia tahun 2011 dalam Rindu Purnama sebagai nominasi pemeran pendukung pria terbaik (Piala Citra) (Landung Simatupang, n.d.)

Pada tahun 2015 Landung Simatupang mengeluarkan sebuah karya yang bersumber dari teks kesejarahan yakni Aku Dipenogoro! Karya tersebut merupakan naskah drama yang terdiri dari tiga bagian, bagian pertama berjudul Sang Pangeran di Magelang dan Batavia: Penangkapan dan Pengasingan, yang kedua adalah Sang Pangeran di Tegalrejo: Nujum Sang Eyang Buyut, dan yang ketiga Sang Pangeran di Fort Rotterdam: Menyongsong Ajal. Dalam artikel ini akan dibahas mengenai hubungan antara $A k u$ Dipenogoro! Karya Landung Simatupang yang merupakan kumpulan tiga naskah drama karya Landung Simatupang dengan Kuasa Ramalan karya Peter Carey yang merupakan catatan sejarah perjalanan Pangeran Dipenogoro. Dari hubungan tersebut akan dilihat pergeseran atau perubahan yang terjadi pada karya Landung Simatupang terhadap sumber rujukan tersebut. 
Vol. 3 No. 1

Juni 2021

e- ISSN 2685 - 0559

p- ISSN 2684 - 673X

\section{KAJIAN PUSTAKA}

Kajian tentang Dipenogoro
pernah dilakukan oleh R.B.
Armantono dengan memaparkan film monolog Dipenogoro yang berbiaya rendah dan memperlihatkan tentang pandangan masyarakat dalam menghadapi permasalahan dalam kehidupan (Armantono, 2019). Adapun (Sahid et al., 2019) juga melakukan kajian tentang Dipenogoro yang terdapat dalam naskah drama $A k u$ Dipenogoro! karya Landung Simatupang. Dalam kajian yang dilakukan oleh (Sahid et al., 2019) memaparkan karakter yang dibangun oleh tokoh Dipenogoro dalam Aku Dipenogoro! Yang merupakan kebalikan dari karakter tokoh De Kock. Selain itu juga mengungkapkan bahwa dalam karya Landung Simatupang itu terdapat kontradiksi situasi antara Tegalrejo dengan Mataram pada masa Mangkubowono II. Menilik dua kajian tersebut, pembahasan Dipenogoro sejauh pengetahuan penulis belum menyentuh ranah representasi karya Peter Carey dengan Kuasa Ramalannya dengan naskah drama Aku Dipenogoro! karya Landung Simatupang secara khusus meskipun ada beberapa tulisan yang mengungkapkan relevansi antara Kuasa Ramalan dengan Aku Dipenogoro!

Adapun kajian resepsi terhadap karya sastra juga dilakukan oleh beberapa peneliti lain, seperti Baihaqi yang melakukan kajian resepsi terhadap cerita Perang Bubat yang terdapat dalam novel
Niskala karya Hermawan Aksan. Dalam kajiannya melihat bahwa pengarang sebagai kreator dan pembaca melakukan resepsi terhadap cerita Perang Bubat dalam novel Niskala tergantung dari tujuannya dalam melakukan interpretasi suatu masalah tertentu (Baihaqi, 2015). Selain itu, Swandayani, dkk juga menggunakan teori resepsi untuk membongkar resepsi media Indonesia terhadap penulis-penulis Prancis dan Jerman. Dalam kajiannya melihat pembacaan terhadap penulis-penulis Perancis dan Jerman yang diresepsi oleh media cetak Indonesia. Dalam pembacaan itu, tampak adanya tanggapan positif oleh penulis resensi Indonesia dan adanya kontruksi sosial dalam keilmuan yang dibangun oleh media massa Indonesia serta adanya trendsetter pemikiran di Indonesia yang dilakukan oleh media massa Indonesia (Swandayani et al., 2013).

Apabila menilik penggunaan teori resepsi yang dilakukan oleh peneliti terdahulu, dapat diambil garis besar bahwa dalam penggunaan teori resepsi tidak hanya berlaku pada karya sastra ke karya sastra tetapi dapat juga dilakukan dengan formasi karya sastra ke karya nonsastra atau karya nonsastra ke nonsastra. Dalam hal ini pembaca melakukan respon terhadap hasil bacaannya. Adapun Fish dalam Allen bahwa pembaca tidak hanya sekedar membaca (bukan pembaca yang sederhana). Pembaca melakukan pembacaan terhadap teks-teks yang ada sudah memiliki modal berupa harapan, 
Vol. 3 No. 1

Juni 2021

e- ISSN 2685 - 0559

p- ISSN 2684 - 673X

asumsi, dan pengalaman. Dalam pembacaan suatu karya (teks) dengan strategi interpretif yang berbeda akan melahirkan suatu hasil pembacaan (teks) yang berbeda (Allen, 2004). Oleh karena itu pembacaan terhadap Peter Carey sebagai teks sejarah bisa melahirkan teks yang lain yakni Aku Dipenogoro! sebuah naskah drama karya Landung Simatupang.

\section{METODE PENELITIAN}

Dalam kajian ini menggunakan metode penelitian kualitatif dengan objek material keseluruhan struktur yang terdapat dalam $A k u$ Dipenogoro! Karya Landung Simatupang. Adapun objek formal dalam penelitian ini adalah representasi dari karya Peter Carey terkait Pangeran Dipenogoro yang terdapat dalam Aku Dipenogoro! karya Landung Simatupang (Faruk, 2012). Kajian ini melalui beberapa tahapan yakni (1) pembacaan objek material secara seksama dan dilakukan berulang-ulang, mencari relevansi objek material (Aku Dipenogoro!) dengan karya Peter Carey tentang Pangeran Dipenogoro dalam bukunya Kuasa Ramalan, (3) melakukan penarikan kesimpulan atas hasil pembacaan Aku Dipenogoro! karya Landung Simatupang dan Kuasa Ramalan karya Peter Carey. Alur dalam kajian ini akan digambarkan dalam bentuk diagram sebagai berikut.

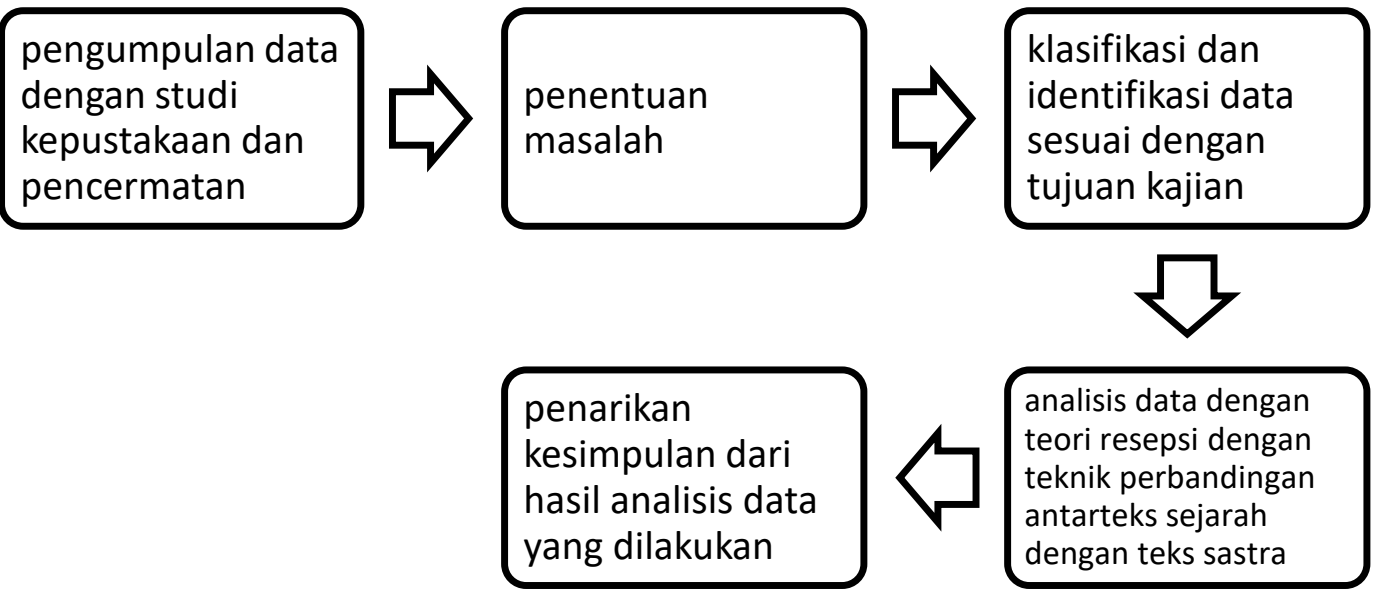

\section{HASIL DAN ANALISIS}

4.1. $\quad$ Sang Pangeran di Magelang dan Batavia: Penangkapan dan Pengasingan

Naskah ini berkisah mengenai proses penangkapan Pangeran Dipenogoro dan proses pengasingannya. Sebelum pada keberhasilan Belanda menangkap
Dipenogoro, Dipengoro menerima pertanda (wangsit) bahwa perjalanan perjuangannya tidak mencapai tujuan. Pejuangannya siasia, yang tersisa hanya mati di Jalan Tuhan dengan melepas nyawa dalam pertempuran. Landung mengakhiri naskahnya dengan tembang maskumambang yang mengisahkan 
Vol. 3 No. 1

Juni 2021

e- ISSN 2685 - 0559

p- ISSN 2684 - 673X

mengenai perjalanan Dipenogoro menuju Manado.

Cerita dalam naskah ini tidak terlalu berbeda jauh dengan Kuasa Ramalan hanya bagian-bagian tertentu saja yang tidak ditampakkan dalam Aku Dipenogoro! Berikut kutipan yang menunjukkan keindentikan antar kedua teks karya tersebut.

Pada 11 November 1829, hari ulang tahuunnya yang keempat puluh empat, Sang Pangeran nyaris tertangkap pasukan gerak cepat ke-11 di bawah komando Mayor Michiels. Peristiwanya terjadi di wilayah Pegunungan Gowong, sebelah barat Kedu. Sang Pangeran terpaksa terjun ke jurang, bersembunyi di balik ketinggian rumput gelagah. Demikianlah ia lalu berhasil lolos dari pasukan Belanda dan Ternate.

Dengan meninggalkan beberapa ekor kuda miliknya, tombak pusaka Kiai Rondhan, dan peti berisi busana untuk perang suci,... (Simatupang, 2015)

Sementara pada Kuasa Ramalan Peter Carey, pernyataan mengenai lolosnya Pangeran Dipenogoro juga dijelaskan sebagai berikut,

Tidak lama kemudian pada 11 November 1829, hari ulang tahunnya yang ke-44, ia hampir tertangkap oleh pasukan gerak cepat ke-11 yang dipimpin oleh Mayor A.V. Michiels di daerah pegunungan Gowong sebelah barat Kedu. Waktu itu, sang Pangeran terpaksa terjun ke jurang dan bersembunyi di balik rumput gelagah tinggi untuk bida lolos dari pasukan Belanda dan Ternate. Dengan meninggalkan beberapa ekor kuda miliknya, tombak pusaka, dan peti pakaian, ... (Carey, 2011a)

Kedua kutipan di atas menunjukkan adanya persamaan antar kedua teks yang lahir dari tangan pengarang yang berbeda. Meskipun pada kutipan yang kedua tidak menunjukkan nama tombak pusaka Pangeran Dipenogoro yang dikatakan pada kutipan pertama sebagai tombak pusaka yang bernama Kiai Rondhan. Selain itu, untuk peti pakaian dalam Peter Carey oleh Landung Simatupang tidak hanya dikatkaan sebagai peti pakaian namun ditambahi kegunaan pakaian itu yang diperuntukkan untuk perang suci.

Beberapa hal yang sama persis dan ditulis oleh Landung Simatupang dengan sedikit sekali perubahan kata yakni isi surat yang dibuat oleh Pengalasan. Pengalasan berusaha mendirukan Dipenogoro dengan menulis sepucuk surat untuk menggambarkan syarat-syarat dari "Yang Mulia Sultan Jawa" demi tercapainya penyelesaian damai (Simatupang, 2015). Namun 
Vol. 3 No. 1

Juni 2021

e- ISSN 2685 - 0559

p- ISSN 2684 - 673X

persamaan tersebut ada bagian yang tidak dikemukakan oleh Landung bahwa Pengalasan melakukan hal tersebut untuk menarik hati petinggi Belanda dan mendapatkan kedudukan serta gaji seperti halnya Sentot (Simatupang, 2015).

\subsection{Sang Pangeran di Tegalrejo: Nujum Sang Eyang Buyut Naskah drama yang kedua ini, mengisahkan mengenai} kehidupan Pangeran Dipenogoro di Tegalrejo dan ramalan yang dilontarkan oleh Sultan Mangkubumi tentang Pangeran Dipenogoro ( nama kecil: Bendoro Raden Mas Mustahar) kepada permaisurinya Ratu Ageng. Seperti kutipan berikut, ...berkatalah Sultan pertama kepada permaisuri, Ratu Ageng:

“ Cicitmu ini kelak, ketahuilah, sudah kehendak Yang Mahakuaasa, akan menjadi tokoh dalam peristiwa besar. la akan menyebabkan kerusakan dahsyat pada Belanda, lebih dahsyat dari yang pernah kutimbulkan dulu. Sedang kelanjutannya wallau'alam, tak seorang pun tahu."(Simatupang, 2015)

Pada kutipan di atas yang menceritakan ramalan terhadap kehidupan Dipenogoro tidak jauh berbeda dengan apa yang dituliskan oleh Carey bahwa Dipenogoro diramlakan oleh Sultan Mangkubumi akan mendatangkan kehancuran yang lebih hebat bagi Belanda daripada Sultan sendiri selama Perang Giyanti (1746-1755), akan tetapi hasil akhirnya tidak dapat dipastikan, karena hanya Tuhan Yang Mahakuasa yang mengetahui segalanya (Carey, 2011b)

Hampir semua bagian di naskah drama kedua ini, isinya tidak jauh berbeda dengan tulisan Carey dalam Kuasa Ramalan. Tokoh-tokoh yang disebutkan di dalam naskah tidak ada perbedaan. Hanya beberapa tokoh yang berbeda digunakan oleh Landung Simatupang untuk menghidupkan situasi dalam pementasan drama. Hal tersebut dapat dilihat dari penggunaan penabuh gamelan yang memberikan iring-iringan musik untuk memberikan efek yang drmatis terhdap pementasan/ pertunjukkan drama. Pada awal naskah dijelaskan adanya tembang sinom untuk pembuka pertunjukkan. Kemudian ada bebrapa iringan music yang digunakan. Seperti suara music yang samar-samar, suara bedug, lonceng sapi, suara orang mengaji (Simatupang, 2015).

Suara-suara tersebut memiliki makna bagi sebuah pertunjukkan yang mempertegas performance. Misalnya suara bedug dibunyikan mencerminkan adanya citra Islam dalam pertunjukkan. Bedug secara tidak langsung menjadi ciri dari kehidupan masyarakat Muslim. Bedug sebagai alat untuk memanggil uamat Muslim untuk melakukan ibadah. Bedug dan Islam tidak dapat dipisahkan. Hal tersebut dipertegas dengan suara orang 
Vol. 3 No. 1

Juni 2021

e- ISSN 2685 - 0559

p- ISSN 2684 - 673X

mengaji. Maka dari bunyi-bunyi yang dinarasikan oleh Landung Simatupang dalam naskahnya yang kedua ini, Landung berusaha memberikan gambaran bahwa kehidupan Dipenogoro tidak lepas dari religiusitas.

Selain itu, beberapa hal yang tidak terdapat di dalam Carey, yakni lantunan tembang sinom. Tembang itu mengisi di sela-sela adegan untuk masuk ke adegan selanjutnya. Tembang itu ada yang diucapkan ada juga yang dinyanyikan. Di samping itu juga pada naskah yang kedua ini, terdapat dialog antar penabuh lesung yang di dalam Carey hanya kalimat-kalimat yang berisi pertanyaan mengenai keadaan Tegal Rejo. Namun oleh Landung Simatupang pertanyaan tersebut dikemas dalam bentuk dialog yang diperankan oleh tiga penabuh lesung. Seperti pada kutipan berikut,

Penabuh Lesung I:

"Lalu bagaimana dengan Tegalrejo sendiri?"

Penabuh Lesung 2:

"Ya, seperti apa keadaan pemukiman yang namanya sarat dengan makna ini, Tegalrejo, Lahan, nan Makmur?'

Penabuh Lesung 3:

"Lahan nan Makmur? Tempat ini? Ah! Seperti apakah tempat ini sekitar dua abad yang lalu?"(Simatupang, 2015)

Bagian yang lain dalam naskah ini, menceritakan mengenai sakitnya Ratu Ageng akibat terjatuh ke dalam salah satu tambak di Tegalrejo (Simatupang, 2015). Terceburnya Ratu Ageng ke dalam tambak di dalam Carey dinyatakan tercebur di kolam yang masih dalam dugaan bahwa salah satunya tempat Ratu tercebur yang membawanya menuju ajal (Carey, 2011b). Di sini jelas ada perbedaan kalimat yang digunakan oleh Landung dengan Carey. Landung mengatakan terjatuh dalam salah satu tambak, sementara Carey masih menduga bahwa salah satu kolam itu kemungkinan tempat tercerburnya Ratu. Di sini Landung membuat sesuatu mnejadi jelas, sementara Carey masih berada pada posisi kira-kira. Hal ini kemungkinan berkaitan dengan kepentingan dari sebuah pertunjukkan.

Untuk mendapatkan visualisasi dan kemudahan dalam penyampaian pesan, maka sesuatu yang sifatnya tidak jelas diperjelas. Dalam Carey hanya dijelaskan bahwa Ratu Ageng jatuh ke dalam kolam seperti kuitpan berikut, ...,dan kolam-kolam (salah satunya diduga tempat Ratu Ageng tercerbur pada awal peyakit yang mengakibatkan kematiannya).... (Carey, 2011b). Sementara dalam Landung dikatakan bahwa Ratu mengalami demam. Seperti pada kutipan berikut, ...Ratu terserang demam tinggi setelah tercebur ke dalam salah satu tambak di Tegalrejo (Simatupang, 2015).

Kemudian naskah ini berkisah setelah sakitnya Ratu Ageng, suasana mencekam karena Gunung Merapi mulai meletus pada 
Vol. 3 No. 1

Juni 2021

e- ISSN 2685 - 0559

p- ISSN 2684 - 673X

22 September yang disusul dengan serangkain letusan gunung kembar yang seolah-olah menyiratkan makna khusus yang mengingatkan pengalaman Ratu Ageng melahirkan Sultan kedia pada Maret 1750. Namun dalam Carey jilid 2 hanya diulas adanya letusan Gunung Merapi yang diambil dari Babad Dipenogoro seperti berikut:

Gunung Merapi terbakar pucuknya bagai terlontar ke langit Yogyakarta serasa tertutup olehnya. Langit berubah menjadi api. [dan] gemuruh mengegntarkan; ia menggelegar dan mengguntur, Apinya memancar ke segala arah. Dalam kegemparan besar, semua di mana-mana orang berusaha sekuatnya cari selamat. (Carey, 2011a)

Tanggal meletusnya Gunung Merapi dalam Landung Simatupang dan Peter Carey tercatat berbeda. Landung Simatupang mengatakan mulai 22 September, namun Peter Carey Gunung Merapi meletus antara 28 dan 30 Desember.

\subsection{Sang Pangeran di Fort Rotterdam: Menyongsong Ajal \\ Awal naskah drama yang} ketiga ini dimulai dengan tembang mijil, kemudian terdapat narrator pendamping pertama yang berkisah kelahiran bayi yang bernama Mustahar- Bendoro Raden Mas Mustahar. Bayi yang dilahirkan dari rahim Raden Ayu Mangkorowati yang bukanlah seorang permaisuri. Bayi itu yang ketika besar akan bernama Pangeran Dipenogoro, pemimpin Perang Jawa. Kemudian narator pendamping kedua berkata mengenai pertemuan Bendoro Raden Mas Mustahar dengan kakek buyutnya, Sultan Hamengkubuwono I, yang kemudian bersabda. Sabda Sultan ini dibawakan oleh narator pendamping I seperti pada kutipan berikut,

" Sudah kehendak Yang Mahaskuasa, cicitku ini kelak akan menjadi tokoh peristiwa besar. la akan menyebabkan kerusakan dahsyat pada Belanda, lebih dahsyat dari yang dulu pernah kutimbulkan, Namun kelanjutannya, tak seorang pun tahu. Wallahu'alam."(Simatupang, 2015)

Apabila diamati akan terlihat perbedaan perkataan Sultan mengenai masa depan Bendoro Raden Mas Mustahar. Pada naskah kedua yang berjudul Sang Pangeran di Tegalrejo: Nujum Sang Eyang Buyut Sultan berkata kepada permaisurinya yakni Ratu Ageng. Sehingga kata yang dilontarkan adalah cicitmu, namun pada naskah ketiga ini yang berjudul Sang Pangeran di Fort Rotterdam: Menyongsong Ajal Sultan berkata sendiri atau bermonolog.

Setelah Sultan bermonolog melalui narator pendamping 
Vol. 3 No. 1

Juni 2021

e- ISSN 2685 - 0559

p- ISSN 2684 - 673X

pertama, kemudian dilanjutkan oleh monolog dari Pangeran Dipenogoro Cilik. Pada monolog ini, dikisahkan pergantian nama kecil ke nama akil balig yang bernama Raden Mas Ontowiryo dan Ratu Ageng yang tinggal di Tedalrejo. Selajutnya narator utama bercerita mengenai perempuan-permpuan di sekeliling Raden Mas Ontowiryo. Di sini juga dikisahlan mengenai asal usul Raden Mas Ontowiryo (Pangeran Dipenogoro) yang memiliki darah Madura, darah Sumbawa, darah desa, yang diinterpretasikan sebagai persekutuan ombak dan gelombang Nusantara. Selain itu, dikisahkan juga kehidupan Dipenogoro dalam meneladani Ratu Ageng dan kiai (Simatupang, 2015). Pada naskah ketiga ini, oleh Landung Simatupang pada beberapa bagian dibentuk dalam bentuk bait. Kemungkinan maksud Landung Simatupang bagian yang berbentuk bait-bait seperti puisi itu diucapkan seperti membaca puisi ketika dilakukan pertunjukkan atas naskah ini.

Secara garis besar ketiga judul naskah yang dituliskan oleh Landung dengan Carey tidak jauh berbeda hanya saja kemasan yang ditawarkan berbeda. Landung mengemas untuk seni pertunjukkan sementara Carey mengemas dalam bentuk tulisan yang sifatnya ilmiah berdasarkan dari penelitiannya yang bertahun-tahun.

Landung menghidupkan teks-teks kesejarahan dalam visual dan gerak. Hal tersebut ditunjukkan dengan teks yang menyatakan adanya iringan musik, tembang dan lakon- lakon lain yang dimasukkan dalam Aku Dipenogoro!. Lakon narator dan iringan musik serta tembang tidak akan didapati dalam Kuasa Ramalan Peter Carey.

\section{KESIMPULAN}

Kedua karya tersebut sebagai
sebuah karya yang mampu memperkaya pengetahuan bagi pembacanya. Karya Landung mengenai Aku Dipenogoro! menunjukkan ada tanggapan pembaca (Landung Simatupang) terhadap teks-teks lain (Peter Carey dengan Kuasa Ramalan). Hal tersebut membuktikan bahwa sebuah karya lahir tidak lepas dari teks-teks lain atau karya yang lain. Karya terdahulu dapat menjadi inspirasi bagi pengarang untuk melahirkan sebuah karya yang berbeda. Adapun perubahanperubahan bentuk yang dilakukan oleh Landung Simatupang dalam $A k u$ Dipenogoro! merupakan bentuk improvisasi untuk mendapatkan efek-efek tertentu dan nilai estetis mengingat bahwa teks $A k u$ Dipenogoro! sebuah naskah drama yang akan dipentaskan.

\section{REFERENSI}

Allen, P. (2004). Membaca dan Membaca Lagi: [Re]interpretasi Fiksi Indonesia, 1980-1995. Indonesia Tera.

Armantono, R. B. (2019). Monolog Dipenogoro. Institut Seni Indonesia Surakarta.

Baihaqi, I. (2015). Resepsi Cerita Perang Bubat dalam Novel 
Vol. 3 No. 1

Juni 2021

e- ISSN 2685 - 0559

p- ISSN 2684 - 673X

Niskala Karya Hermawan Aksan.

Transformatika, 11(2), 61-71.

Carey, P. (2011a). Kuasa Ramalan:

Pangeran Dipenogoro dan Akhir

Tatanan Lama di Jawa, 17851855 Jilid 2. KPG.

Carey, P. (2011b). Kuasa Ramalan: Pangeran Dipenogoro dan Akhir Tatanan Lama di Jawa, 17851855 Jilid I. KPG.

Faruk. (2012). Metode Penelitian Sastra: Sebuah Penjelajahan Awal. Pustaka Pelajar.

Junus, U. (1985). Resepsi Sastra: Sebuah Pengantar. Gramedia.

Landung Simatupang. (n.d.).

Sahid, N., Purwanto, P., \& Marianto, M. D. (2019). The Meaning of Opposing Element in the Drama Aku Diponegoro. Proceedings of the 2nd International Conference on Arts and Culture (ICONARC 2018), 271, 216-217.

Simatupang, L. (2015). Aku Dipenogoro! KPG.

Swandayani, D., Santoso, I., \& Wilujeng, N. C. S. (2013). Resepsi Media Indonesia terhadap Filsuf-Penulis-Pemikir Prancis dan Jerman. UNY Press. 